\title{
Participatory Evaluation of Facilities and Infrastructure at Public Hospital of Sabang City in Facing a Fire Disaster
}

\author{
Saifan Ramadhana ${ }^{1}$, Ismail $\mathrm{AB}^{2}$, Taqwaddin Husin ${ }^{3}$ \\ ${ }^{1}$ Masters in Science Disaster, University Syiah Kuala, Banda Aceh 23111, Indonesia \\ ${ }^{2}$ Faculty of Mathematics and Natural Sciences, University Syiah Kuala, Banda Aceh, \\ Indonesia \\ ${ }^{3}$ Faculty Law, University Syiah Kuala, Banda Aceh, Indonesia \\ \{saifanramadhana21@gmail.com\}
}

\begin{abstract}
Fire is the occurrence of unwanted fire or fire that is not in place, the disaster is formed by three elements, namely fuel or combustible materials, oxygen, and heat sources. This study aimed to evaluate the facilities and infrastructure of Sabang hospital in preparedness against fire. This study used descriptive methods with a qualitative approach through observation. The results of the study found that there are still aspects of the facilities for fire disaster management at Sabang hospital which are not yet available such as fire alarms; fire hydrant; emergency telephone line; evacuation route; exit sign; emergency exit door; sloping path; and gathering points. Meanwhile, aspects that have been available include prohibited smoking signs and also light fire extinguishers. It can be concluded that the facilities and infrastructure of Sabang hospital in fire preparedness are not eligible. Thus, there must be an improvement to the management of Sabang Hospital in order to meet all aspects of infrastructure facilities for fire disaster management systems in accordance with the Technical Guidelines for Hospital Infrastructure, Active Fire Protection System by the Ministry of Health of the Republic of Indonesia.
\end{abstract}

Keywords: Preparedness, Fire, Infrastructure, Hospital.

\section{Introduction}

Fire disaster can occur anywhere and anytime, one of which is in a building in an area. Indonesia is one of the countries prone to fires. According to the office of Fire and Disaster Management (DPK-PB), it was found as many as 8243 cases of fires in Jakarta, Indonesia starting from 1998 to 2008 by making losses up to Rp. 1,255,091,940,080. Meanwhile, the data gathered by the Aceh Disaster Management Agency (BPBD) of Aceh Province in 2012, show the incidence of fires in Aceh Province reached 412 cases with loss of Rp. 33,230,213,000. Therefore, the building developer must provide a fire protection system. Government has been made rule that is PERMEN PU No. 20 of 2009 concerning Technical Guidelines for Fire Protection Management in Buildings and every building owner/user must utilize the building in accordance with the functions stipulated in the building permit including fire risk management starting from the periodic maintenance, maintenance and inspection activities of the system fire protection and preparation of trained personnel in fire control [1]. when the fire occurs in the building, it is mentioned that each building has an area of at least 5,000 $\mathrm{m} 2$ and especially hospital building that has more than 40 places of hospitalization, required to implement the MPK (Fire Protection Management).

Hospital is one of the buildings that have a high risk of the fire incident. This can be seen from the many potential sources of danger and its inhabitants. Thus, the presence of extinguishing equipment such as sprinklers, APARs, hydrants, and smoke or temperature detectors is very important. Besides that, the existence of fire 
management is needed when a fire disaster has occurred [2]. So that based on previous researches, it was found that the things that have the potential to cause fires in hospitals included the use of several types of chemicals that are at risk of exploding and burning such as flammable chemicals; ethanol, alcohol, propanol. These types of chemical are very flammable. In addition, the types of oxidizing chemicals such as benzoyl peroxide will cause a fire if they react with other chemicals.

Facilities and infrastructure preparedness is a preventive effort carried out to anticipate unwanted incident. Facilities may be understood as any kinds of means, equipment, and other facilities that serve as the main too/auxiliary in the execution of the work, and social functioning in the framework of the interests of those who are associated with the organization [3]. While infrastructure means that all facilities that complement the needs of the facilities owned and are permanent or cannot be moved [4]. Based on that definition, then it can be said that basically the facilities are related to tools that are directly used for certain purposes, while the infrastructure is in the use of a means of supporting such facilities. A hospital could be said well once it corresponds with PERMEN PU No. 20 of 2009 [1] concerning Technical Guidelines for Management of Fire Protection in Buildings including necessary means such as APAR, Sprinkler/Hydrant, Fire Alarm and Channel telephone special circumstances emergency. While infrastructure needed among others are track evacuation fire, stairs emergency, ramps, signs instructions out, sign location gathers together and sign banned smoking.

Within 4 years to behind, the Regional Public Hospital (RSUD) of Sabang used as the object of the study had no history of fire disaster occurrence. However, preparedness efforts remain necessary to fire continuously. The authors' consideration is to take the location of research in the Sabang Hospital, including the potential for fires to occur at any time in Sabang Hospital because of limited infrastructure, especially fire prevention, limited access to assistance (because of the island area) in the building and Sabang which is often visited by local tourists and foreign tourists so that with this situation of Sabang RSUD is ideally ready to provide maximum service to the community including the availability of infrastructure facilities for fire disasters. Therefore, that aim from this research is to evaluate the infrastructure facilities of the Sabang Hospital in fire preparedness.

\section{Method}

This research was descriptive qualitative research. The data were obtained through observation, observation, and direct examination, and literature reviews reference of relevant theory with cases or problems. Theoretical references obtained through literature studies will serve as a basis for conducting research in the field which was in Sabang Hospital. Data of the research were divided into two sources namely primary data and secondary data. Primary data regarding facilities and infrastructure were gathered through observation directly on research location. While secondary data were based on studies literature related to previous research from Sabang RSUD and Service Health of Sabang

\section{Result and Discussion}

\subsection{Facilities at Sabang Hospital}

The results of the study found that there were still a number of fire disaster management facilities at Sabang Hospital that were not yet available and those that were available but did not meet the requirements set by the "Directorate of Medical Support Services and Health Facilities of the PER.04/MEN/1980 [2] concerning the Guidelines of Hospital Technical Infrastructure, Active Fire Protection System ".

The findings through observation on the facilities of the Sabang Hospital in fire preparedness showed that some aspects of the Hospital's facilities are not available. These aspects are like a fire alarm; fire hydrant; emergency telephone line; evacuation route; exit sign; emergency exit door; sloping path; and gathering points. Meanwhile, aspects that are available are only limited to smoking signs and also light fire extinguishers. To be clearer, the completeness of the facilities can be seen in Table 3.1 .

Table 3.1 shows that the data from observations found that the Sabang hospitals do not provide some vital means as follow:

Alarm; is a means that is actually very vital because it is a warning to notify people in the hospital to immediately evacuate themselves to a safe place in an emergency. If an alarm is not available, of course, it will be very difficult to notify everyone who is in the hospital at the Sabang if a fire incidence occurs. The alarm that does not emit a sound in the form of a heat, smoke and flame detector is a tool that is also important because this tool serves as an early detection if there is a potential for fire, both automatically and manually, to minimize the impact of losses in either material loss or loss of life.

Water hoses and/or hydrants; is also a must-have facility in every hospital. This is very clearly needed if there is a fire for the initial steps to prevent the fire from escalating before the fire department arrives at the location. If 
there is no water hose and/or fire hydrant, then, it is possible that the fire will quickly enlarge and burn all existing rooms and hospital equipment

Special telephone line in an emergency; is an actual supporting facility that must be provided in the hospital. For this particular telephone line, if there is a fire disaster and the usual communication lines become off, this particular telephone line can function optimally to call for help.

The facilities studied through observation refer to fire alarm, heat detector, smoke detectors, fire extinguisher, water hoses and/or hydrants, a special telephone line, emergency evacuation routes, door/path emergency exit, ramp, and gathering point. The type of APAR media owned by the Hospital of Sabang is powder or chemical powder, this media has several advantages such as it is easy to control and can be used to extinguish fires class A, B, and C. This is very suitable because the Hospital of Sabang City has the risk of this type of fire.

The results of the study found that there were still a number of aspects of fire disaster management facilities in the Sabang Hospital that were not yet available according to the standards regulated by the Directorate of Medical Support Services and Health Facilities of the Indonesian Ministry of Health in 2012 [3] concerning Technical Guidelines for Hospital Infrastructure, Active Fire Protection Systems.

\subsection{Infrastructure at Sabang Hospital}

Fire disaster management infrastructure is also an important aspect of the overall fire prevention system in the hospital. The following is a table that shows a summary of the results of observations of fire disaster management infrastructure in Sabang Hospital Based on Table 3.2, it can be seen that this aspect of fire disaster management infrastructure at Sabang hospitals that have been provided are 1) the primary evacuation route as the main access lane at Sabang Hospital and liaison direction to self-evacuation when happening disaster; 2) alternative energy sources when the electricity goes out. The existence engine generator as function lighting reserve when Flow electricity goes out makes it easy to evacuate when disaster happens. 3) There are also no smoking signs.

Infrastructures that are not owned in Sabang City Hospital, namely:

Alternative evacuation routes; is an important infrastructure that is intended if the main route experiences a deadlock due to fire and is impassable, so an alternative evacuation route is needed for the process of self-rescue.

Signs/symbols towards the evacuation route; is also important, because to facilitate the evacuation process, if there is no sign, the residents or guests will experience confusion when saving themselves due to panic conditions.

Signs / symbols along the route; also need to be provided because if an exit cannot be seen directly by visitors or users of the building, a sign with an arrow indicates the direction should be provided in the corridor, the road leading to a large room, lobby and the like which gives an indication of direction to the required exit

Lighting along the route; also needs to be concerned, because if there is a fire, the electricity will automatically turn off and the hospital will darken. Therefore, lighting is needed on the evacuation line that does not rely on electricity such as stickers or directions that are brightly colored if it is in a dark condition or it could also be a lamp that stores electrical energy which automatically turns on when the electricity goes out.

Signs/instructions OUT/EXIT; which serves as a guide for evacuation in the event of a fire disaster where all people in the hospital will mostly experience panic. The exit signs will help facilitate the evacuation process to find a safe place during a fire disaster.

Emergency doors/exits; are infrastructures that should be provided and these that aims to shorten the time when the evacuation process occurs in the event of a disaster.

Ramp; is a facility that should be included in every hospital. A sloping path will greatly help patients who are in wheelchairs or in bed to push when hospital employees and relatives of patients in evacuating patients who cannot get up from their beds

Location points gathering as the end of the evacuation route; this infrastructure shows if the place which is the final point is a safe place from the catastrophic fire. However, at RSUD Sabang, such infrastructure does not seem to meet the terms as gathering point location because the open field at Sabang City Hospital is relatively small since areas have been filled for two and four-wheel vehicles parking areas.

\section{Conclusion}

Based on the results of research on the evaluation of facilities and infrastructure at Sabang Hospital in facing fire disasters, it can be concluded that "the facilities and infrastructure of the Sabang Hospital in fire preparedness do not meet the requirements". 
Table 1. The Completeness of Fire Disaster Management Facilities at Sabang City Hospital

\begin{tabular}{|c|c|c|c|c|c|}
\hline No & Aspect & Available & None & $\begin{array}{l}\text { Fit the } \\
\text { standard }\end{array}$ & Information \\
\hline \multirow[t]{4}{*}{1} & Fire Alarm & & & & \\
\hline & Heat detector & & $\sqrt{ }$ & No & Not available \\
\hline & Smoke detector & & $\sqrt{ }$ & No & Not available \\
\hline & Flame detector & & $\sqrt{ }$ & No & Not available \\
\hline \multirow[t]{4}{*}{2} & Light fire extinguishers & & & & \\
\hline & a. In the inpatient room & $\sqrt{ }$ & & No & $\begin{array}{l}\text { There are no instructions for use } \\
\text { and no regular maintenance }\end{array}$ \\
\hline & b. In the vehicle parking area & & $\sqrt{ }$ & No & $\begin{array}{l}\text { There are no instructions for use } \\
\text { and no periodic maintenance }\end{array}$ \\
\hline & c. In the corridor/hallway to the exit & $\sqrt{ }$ & & No & $\begin{array}{l}\text { There are no instructions for use } \\
\text { and no periodic maintenance }\end{array}$ \\
\hline \multirow[t]{4}{*}{3} & Sprinkler / Fire Hydrant & & & No & Not available \\
\hline & a. Water hose inside the hospital & & $\sqrt{ }$ & No & Not available \\
\hline & b. Fire hydrant & & $\sqrt{ }$ & No & Not available \\
\hline & c. Water sprinkler & & $\sqrt{ }$ & No & Not available \\
\hline 4 & Emergency telephone line & & $\sqrt{ }$ & No & Not available \\
\hline
\end{tabular}

Source: Observation of lapngan (processed))

Table 2. The Completeness of Fire Disaster Management Infrastructure at Sabang City Hospital

\begin{tabular}{|c|c|c|c|c|c|}
\hline No & Aspect & Available & No & $\begin{array}{c}\text { Fit the } \\
\text { standard }\end{array}$ & Information \\
\hline \multirow{7}{*}{1} & Evacuation route & & & & \\
\hline & a. Primary evacuation route & $\sqrt{ }$ & & Yes & $\begin{array}{l}\text { Corridor connecting } \\
\text { blocks }\end{array}$ \\
\hline & b. Alternative evacuation routes & & $\sqrt{ }$ & No & Not available \\
\hline & c. Sign/symbol towards the route evacuation & & $\sqrt{ }$ & No & Not available \\
\hline & d. Signs/symbols along the route & & $\sqrt{ }$ & No & Not available \\
\hline & e. lighting along the route & $\sqrt{ }$ & & No & $\begin{array}{l}\text { Too decreased and } \\
\text { slippery floors }\end{array}$ \\
\hline & f. Alternative energy sources when & $\sqrt{ }$ & & No & Using a generator \\
\hline 2 & Signs / instructions OUT / EXIT & & $\sqrt{ }$ & No & Not available \\
\hline 3 & $\begin{array}{l}\text { Emergency door/exit (only during an } \\
\text { emergency }\end{array}$ & & $\sqrt{ }$ & No & Not available \\
\hline 4 & Ramp & & $\sqrt{ }$ & No & Not available \\
\hline 5 & $\begin{array}{l}\text { Location points gather as the end of the } \\
\text { evacuation route }\end{array}$ & & $\sqrt{ }$ & No & Not available \\
\hline \multirow[t]{5}{*}{6} & No smoking sign & & & & \\
\hline & a. Around the ICU & $\sqrt{ }$ & & No & Striking placement \\
\hline & $\begin{array}{l}\text { b. Around the emergency room emergency } \\
\text { c. Around the laboratory }\end{array}$ & $\sqrt{ }$ & & Yes & Striking placement \\
\hline & d. Around the surgery room & $\sqrt{ }$ & & Yes & Striking placement \\
\hline & & $\sqrt{ }$ & & Yes & Striking placement \\
\hline
\end{tabular}

Source: Field Observation (processed)

\section{REFERENCES}

[1] Peraturan Menteri Pekerja Umum No. 20, Pedoman teknik manajemen proteksi kebakaran di perkotaan. Jakarta, 2009.

[2] Peraturan menteri tenaga kerja dan transmigrasi No: PER.04/MEN/1980, Tentang syarat-syarat pemasangan dan pemeliharaan alat pemadam api ringan. 1980.

[3] Kementerian Kesehatan RI, Pedoman teknis prasarana rumah sakit sistem proteksi kebakaran aktif. 2012, pp. 1-61. 